\title{
The EU engagement in democracy promotion in post-Soviet Central Asia: the case study of the Kyrgyz Republic - prospects and challenges
}

\begin{abstract}
When Soviet Union collapsed, there were different hypothesis regarding democratic reforms and political system changes in Kyrgyzstan. It was believed that Kyrgyzstan would develop its independent policy and democratic governance. Since early 1990s European countries through OSCE, and later through the EU launched development projects have been playing central role in democracy promotion and civil society development in Central Asia. At the same time, as analysis show geopolitical interests of neighboring powerful states such as Russia and China increased in the region, which resulted the creation of regional institutions such as Shanhai Cooperation Organization (SCO), Collective Security Organization (CSO), Eurasian Economic Union (EEU) and Silk Road Belt Initiative (SRBI). While being the fully-fledged member of China and Russia led regional institutions, Kyrgyzstan is under heavy political and economic influence. Besides, human rights situation in Kyrgyzstan like in other Central Asian countries has been deteriorating for last few years.

Thus, the research paper focuses on interplay between Russia and China for geopolitical dominance in the region, including how it negatively influences for political volatility, civil society suppression and deterioration of human rights issues. Paper equally analyzes European countries engagement in human rights and democracy promotion in Kyrgyzstan. The research considers important to analyze the EU strategy in democratic reforms in Central Asia and to investigate why it matters for the EU.
\end{abstract}

Key words: Central Asia; geopolitics; human rights, democracy promotion

\section{Introduction and aim}

$\mathbf{W}$ hen Soviet Union collapsed, there were different hypothesis regarding democratic reforms and political system changes in Central Asia. If a certain number of scholars argued that the fall of communism would bring the development of political parties, party pluralism accompanied by democratic reforms and active political participation, there were also local experts and scholars who predicted interplay between Russia and China for economic expansion and regional stability will sway over western influence regionally.

Upon independence, with active engagement of international organizations and regional institutions all five countries introduced liberal measures in economic sector and political system. However, none of the CA states integrated democratic values in political system. On the contrary, Central Asian leaders reshaped their post-soviet authoritarian regime with the support of neighboring major powers. Today, after 25 years of Central Asian countries independence, "all Central Asian states embrace nondemocratic rule, variously labeled as personal dictatorships, authoritarian presidentialisms, and neopatrimonial and sultanistic regimes" (Omelicheva, 2015, p. 1). 
Analysis of the post soviet period clearly shows that the European Union, OSCE and USAID launched development projects in Central Asia had a promising role in promoting the Western approach ${ }^{1}$ of civil society development and political participation process. With the fully-fledged membership of Central Asian states in OSCE and partnership and cooperation agreement $\left(P C A^{2}\right)$ between the EU and Central Asian countries, there was a hope for political system changes in the post-Soviet region, which suffered from 70 years of severe suppression of civil society sector. However, as UN reports on human rights issues and OSCE reports on the Human Dimension Implementation for the year 2016 indicate, Central Asia has been identified as a highly problematic region due to human rights violations and suppression of non-state actors in the region.

According to Human Rights Watch's world report for 2016, "The governments of Kazakhstan, Kyrgyzstan, Tajikistan, Turkmenistan, and Uzbekistan arrested and imprisoned government critics, closed down independent groups and opposition parties, and adopted legislation restricting the rights of nongovernmental organizations,"3 which questions why two decade investment of western launched projects (particularly the EU's human rights and democracy path) have been unable to improve Central Asia's record in human rights and freedom of speech? What are secrets of Central Asian leaders to sustain their undemocratic regime?

According to human rights activists and social scientists, human rights violations and civil society crackdown in the post Soviet Central Asia to some extend is directly connected with regime survival attempt of former Communist leaders of Central Asia. Political leadership in Central Asia differs from Central and Eastern Europe as well as from other Former Soviet countries. As two and half decade period of the post soviet shows, all Central Asian presidents established super presidential form of governance which is based on clan and tribal policy in addition to family centered regimes. Besides, all leaders of Central Asia suppress civil society and free media.

If some scholars connect the unsuccessful political system changes with the seventyyear-old communist style of governance, which is deep rooted in the government leaders of Central Asia, a certain number of scholars refer to the geographical location of Central Asia, which is surrounded by two historical overlords - China and Russia. As analysis show geopolitical interests of neighboring Russia and China has increased in the region, resulting the creation of regional institutions such as Shanhai Cooperation Organization (SCO), Collective Security Organization (CSO), Eurasian Economic Union (EEU) and Silk Road Belt Initiative (SRBI).

In this respect, while analyzing deterioration of human rights issues and failure of democratic reforms in the post-Soviet Central Asia, the research paper considers impor-

${ }^{1}$ Western approach in this context implies to western version of civil society which is associated with democracy promotion and human rights values. For last two decades US State Department funded projects of Counterpart International, Civil Society Support Centers and EU funded projects in Central Asia aimed at activating civil society and democracy promotion through activities of non-state actors, which pursue promotion of democracy, human rights, rule of law.

2 Partnership and Cooperation Agreement is a document signed between the EU and Central Asian states in 1996 which paved the way for a broader bilateral relationship, encompassing political dialogue; trade in goods; business and investment.

${ }^{3}$ HRW World report for 2016, retrieved on March 9, 2017, https://www.hrw.org/news/2016/01/27/ central-asia-backsliding-rights. 
tant to study not only the Central Asian leaders priority to regime survival but also the revived interest of Russia and China for geopolitical dominance in the region, at a time when local regimes become less hospitable to western launched democracy promotion projects. In order to narrow down the research, this paper focuses on the post Soviet Kyrgyzstan, which started to face human rights violation and political volatility for last few years. According to freedom House report on nation in transition "Democracy score of Kyrgyzstan in comparison with 2016 has declined, having reached 6 points (5.89 points a year before). As a result, the republic has moved to the category of countries with consolidated authoritarian regime" (Khokhlova, 2017, p. 1).

In this respect, paper investigates democracy promotion in Kyrgyzstan, including civil society sector. It equally examines the European Union's (EU) democracy promotion efforts in the post-Soviet Central Asia, focusing on the case of the Kyrgyz Republic, which accommodates relatively active civil society in the region and the same time identified by experts as one of the most fragile and conflict-affected countries in the post-Soviet space. Finally, research also includes the latest regional initiative developments led by Russia and China, and its impact for authoritarianism revival in Kyrgyzstan.

\section{Political system and leadership in the Post Soviet Central Asia}

It is argued that the seventy-year-old communist style of governance inherited weak civil society in Central Asia, which negatively influence for democratic reforms and political system change in the region. In this regard, Mehrad Haghayeghi pointed out that "although in some republics independence brought about major structural changes that aimed at altering the institutional frameworks of politics, with the exception of Kyrgyzstan, power remained in the hands of the former communist leaders who so far have hindered the process of post-communist democratization" (Haghayeghi, 1996, p. 121). By most scholars view, soviet political culture is deep rooted in government structures of Central Asian states and it has direct link to the failure of political transformation.

With the dissolution of the USSR, former Soviet leaders from the Central Committee took presidential offices in young countries and reshaped their political ideology. For example, Turkmenistan and Uzbekistan aimed at preserving Soviet-era institutions such as kolkhoz, sovkhoz and the one-party system, while Tajikistan, Kyrgyzstan and Kazakhstan integrated clan and tribal networks for political participation. If Nursultan Nazarbayev has been serving as the first and only president in Kazakhstan, the Uzbek president Islam Karimov, whose regime shared Joseph Stalin's style of rule, served 25 years before his death. Like during Soviet times, Uzbekistan and Turkmenistan centralized the decision-making process of social, political and economic issues, whereby the civil society sector remained under severe suppression. Moreover, Uzbekistan and Turkmenistan have been criticized for the heavy control of media as well as the NGO sector while other three Central Asian countries have been also criticized for crackdown in civil society sector.

What is characteristic to power structure in the post Soviet Central Asia is that presidents have been creating super presidential model of governance, accompanied by fam- 
ily structure and clan and tribal networks in business and political spheres. Most experts criticize not only usurpation of power by Central Asian presidents but also tendency to treat their country's economy as a family business (Orozbekova, 2016, p. 1). In her analysis of post-Soviet Central Asian countries, Anna Matveeva argues "Central Asian institutions resemble their Soviet predecessors, but power arrangements within them are different. These are 'hybrid institutions' which are a product of the adaptation of their Soviet predecessors to post-Soviet realities and in which rules are typically blurred" (Matveeva, 2006, p. 15). In this context, Central Asian countries replaced the status of president with the role of Khan or Sultan. Like in the period of the Kokand Kingdom, Central Asian presidents gained absolute power.

If during Soviet times the communist party was monopolizing the political and economic structure, after independence Central Asian society was confronted with the usurpation of business and political power by one family or clan. Family members of presidents including their clan and tribal network members take high state positions and actively control business and private sector. For instance, "in Tajikistan, president tapped his daughter Ozoda Rahmon to head the presidential administration while her husband has been working as deputy head of Tajikistan's central bank" (Orozbekova, 2016, p. 1). In the case of Kazakhstan it is argued that "At age 75, Nazarbayev exercises tight centralized control over the government, and his family plays a key role in maintaining power. For years, high oil prices made it easy for the Kazakh president to divide authority among his family and supporters" (Stratfor, 2015, p. 1).

Without exception all Central Asian business and political structures can be characterized as highly family centered. In addition to this, the term elite also has a popular topicality in the power structure of Central Asian countries. There are certain elite groups such as former Communist leaders' families or clan leaders, who actively participate in monopolization of business and political system. For instance, even in Kyrgyzstan after two revolutions which pursued goal to replace corrupted family and its circle, political system and business sector is still dominated by people from the circle of previous presidents.

The next issue to discuss on civil society crackdown in Central Asia is connected with the government and media relations. In Western society, mass media is perceived as an important tool for achieving the main objectives of democracy promotion and civil society development. However, in authoritarian countries of Central Asia free media is perceived as direct threat to their regime survival. Regarding media relations in Central Asian governments, it is assumed that "the Soviet Union left behind a mixed legacy in the media industry in Central Asia and the other new independent states in its former territory. On the one hand, the mass media were part of the ideological 'superstructure' of the societies. They were foremost an instrument of political command and control" (International Media Support, Copenhagen, 2008, p. 14). Indisputably, Soviet era media policy is deep rooted in government policy of Central Asia. However, it is equally important to take into account the fact that contemporary media, which is equipped with technological innovation and which can influence mass movements (such as in the Arab Spring), is a high concern for the quasi-democratic and authoritarian governments of Central Asia. Free media is perceived as a threat for governmental politics. Free media brings independent movements, and independent view, which in most cases are not in favour of Central Asian dictators. 
Therefore, when one discusses about democracy promotion and civil society development in the post-Soviet Central Asia, it encompasses confrontation between western democratic values and family centered regime.

Former communist leaders and dictators of the region sustain their regime through demonizing western values and describing it as negative external other. In this context, for the western countries it is getting more complicated to engage in liberalizing political and economic system. The last two and half decade investment still did not show visible results, in particular in political power system change.

\section{Regional cooperation in Central Asia}

Central Asia is defined as one of the most problematic regions not only due to human rights violations and undemocratic regimes which suppress civil society but also its fragility to high unemployment and poverty increase its vulnerability to contemporary challenges such as Islamic radicalism, terrorism, drug trafficking, ethnic violence and other forms of complex emergencies, which require regional response. Besides, three of the Central Asian countries are bordered with Afghanistan whereas situation in Afghanistan directly influences the stability in the region.

When one analyzes regional integration policy, Central Asian states became members of several regional institutions or initiatives led by Russia or China. For last two and half decades period Central Asian states joined to regional institutions such as Shanhai Cooperation Organization (SCO), Collective Security Organization (CSO), Eurasian Economic Union and Great Silk Road Belt initiative, which highlights Central Asia's importance for Chinese and Russian economy and development. By social experts view cheap and reliable energy is considered as one of the main driving force for increased geopolitical interest and interplay between China and Russia. In this regard Virginia Marantidou and Ralph A. Cossa stated "China have been investing billions of dollars in the energy sector (which include a series of contracts with Central Asian states while Moscow is especially keen to maintain control of Central Asian energy and resource exports to protect its own position in the market" (Marantidou, Cossa, 2014, p. 1).

Development of regional organizations with Russia and China in Central Asia shows not only increased interests of historical overlords in the region but also their competition for economic expansion and regional dominance. The latest statistics and reports clearly show how Chinese trade with Central Asian region has been exceeding Russian economic turnover with Central Asian countries. In 2015, "China became Uzbekistan's largest trading partner with $\$ 3$ billion worth of trade, Kazakhstan's largest investor with 33 deals delivering $\$ 23.6$ billion to the nation and Turkmenistan's biggest investor in energy sector. In addition, China became a leading partner in Kyrgyzstan and Tajikistan for hydro-power projects" (Kelly-Clark, 2015, p. 1).

While analyzing current regional integration process in the region it can be concluded that Central Asian states see China and Russia led organizations as an opportunity for balancing their alliances- two major players, both of which have greater ambition to economic and political dominance in the region. In the process of re- 
gional intensifications in the frame of Eurasian Economic Union or Great Silk Road initiative, one can also see how these two regional rivals and major players impose new import restrictions in their led regional institutions which focus on increasing dependency of Central Asian states. For instance, Eurasian Economic Union (EEU), which is seen as Moscow's counter response to Beijin's great Silk Road plan that aim at extending China's zone of economic interest in the region, offers opportunity to Moscow to tie economic interdependence of Central Asian countries with Russia. Moreover, since 2014 with the eruption of Ukrainian crisis and with the active engagement of Russia in Syrian conflict, Russia regained its role as security guarantor in the region.

At the same time, local experts also draw attention to shared interests of Russia and China in the region. Both powers have common interest in maintaining regional security which is complicated due to increasing religiosity and development of radical groupings in post-Soviet Central Asia and Chinese Xinjiang region. Since Central Asia obtained independences, number of radical groups and sects such as Hisbut Tahrir, Islamic Movement of Uzbekistan, Turkestan movement, Tabligi Jamoat and others have increased. Central Asian states as well as Russia and China acknowledge that without regional cooperation it would be impossible to address security challenges in the region. Therefore, when one investigates Shanghai cooperation organization and Collective Security Treaty organization, both of these institutions are security oriented.

Most scholars highlight that the role of regional institutions will be vital to solve security challenges and address contemporary issues. Membership of Central Asian countries in Russian and China led regional institutions plays a crucial role to extend economic growth and to confront drug trafficking, terrorism, Islamic radicalism and to secure regional stability. However, when one analyzes main root causes of high unemployment and poverty which increase fragility of Central Asian society to Islamic radicalism, drug trafficking and organized crime, it is tightly connected with high corruption and weak civil society which is suppressed.

A certain number of local experts do not prioritize corruption and civil society crackdown as major issue for the region. By their opinion if economy will develop and political system will be stable corruption, poverty and unemployment will be also solved gradually. In other words in regional integration process in the frame of Russia and China led organizations civil society is lagging behind. Neither Russia nor China care about human rights violations in Central Asia for the sake of their alliance and dominance in the region. Besides, neither Russia nor China accommodates open civil society and free media. Hence, both regional players are not interested in civil society development and democracy promotion in the region. Therefore, it would be relevant to ask what is the future of democracy and civil society development in the post-Soviet Central Asia? And what is the role of the EU and other western countries in promoting democracy in the region?

In this regard, scholars assess "the EU's engagement in Central Asia is one of limited to no impact. The region has become more unstable; democracy is seen by the regimes as a threat to their survival; and human rights have been backsliding" (Boonstra, 2015, p. 1). The latest reports of OSCE and HRW show that Central Asian leaders have less interest in engaging in human rights and democracy discourses. 


\section{The EU engagement in democracy promotion beyond the Europe}

The contemporary understanding of democracy promotion, which includes the issue of active civil society, political and civic participation and the active involvement of non-state actors in social and public issues, derives from the Western countries. The EU, which was established by principles of democracy and western values, is a key player in democracy promotion and civil society development in and beyond the Europe. Democratic values are integral part of the EU strategy and since the fall of communism the nature of EU external policy have been encompassing democracy assistance in global context.

Pavol Demeš, Director for Central and Eastern Europe, German Marshall Fund of the United States stated "once the Iron Curtain was dismantled and CEE countries opened up to pluralistic democracy, multiple public and private players from the West started assisting them" (Demeš, 2010, p. 5). Since the crackdown of the USSR, institutional intensification and enlargement process had powerful impact for democratization, liberalization, formal institution building, and law enforcement in postcommunist block space. It is argued that for Central and Eastern European countries, which shared a certain degree of common cultural value with the West, was relatively smoother to transform for democratic governance than in Balkan or former Soviet Union countries.

There are several tools and mechanisms used by the EU in promoting democracy. One of them has direct linkage with the EU enlargement. The EU accession requirement or so called Copenhagen criteria also played a crucial role for successful democratic reforms in Central and Eastern Europe. For instance, "the policy of conditionality and open doors, associated with foreign assistance, helped Eastern European countries to navigate the transformation and integration processes" (Demeš, 2010, p. 6).

What the vast majority of scholars argue is that the EU integration process has been perceived as the most encouraging instrument for democratic reform processes of candidate and non-member states in the EU's neighborhood. Thus, the EU enlargement has a vital stake to set the adoption of democratic rules and practices as conditions for integration process. This mechanism by most scholars is coined as political conditionality.

However, this political conditionality instrument of the EU is applicable only to potential members and candidate states. Therefore, while analyzing the EU engagement in democracy promotion beyond Europe, one would ask questions such as what mechanisms and instruments are applied to promote democracy and western values? And how the EU can effectively engage in democracy promotion in other regions where other regional powers have more influential mechanisms from security stability, economic growth and other context. For instance, in the case of the post soviet Central Asia, the EU has been actively engaged in democracy promotion through Partnership and Cooperation Agreement signed by the EU and Central Asian countries.

In contrast to the Eastern and Central Europe, Central Asia is far from Brussels and the membership or enlargement instrument is not applicable to the region. Therefore, in the case of Central Asia one can examine the EU engagement in democracy assistance without political conditionality. Moreover, other regional players, Russia 
and China regained their influence in the region and created their regional institutions which allowed them to develop their own mechanism and instruments for integration process. According the latest estimates, China has remained the main economic partner of Kyrgyzstan.

Table 1

Foreign direct investment to Kyrgyzstan by China

\begin{tabular}{|l|c|c|}
\hline & China & The rest of countries \\
\hline Foreign direct investment to Kyrgyzstan in 2005 & 45 million & \\
\hline Foreign Direct investment to Kyrgyzstan for 2014 & 108 million & 103 million \\
\hline Foreign direct investment stock to Kyrgyzstan in 2015 & 984 million & \\
\hline
\end{tabular}

Source: Tabaldieva, 2017.

As table above shows the total amount of foreign direct investment inflows to Kyrgyzstan increased almost ten times from 2014 to 2015. If one compares foreign direct investment inflows to Kyrgyzstan between 2005 and 2015, for ten years period increased 20 times. As for trade turnover between the two countries, in 2015 it reached over $\$ 1.1$ billion which is the highest comparing to Kyrgyzstan trade turnover with other neighboring countries. Some projects under cooperation between the two countries are as follows: "Kyrgyzstan China gas pipeline, the second stage of North South highway, reconstruction and repair of roads in Bishkek, construction of the oil refinery in the country, modernization of the Bishkek Power Station" (Tabaldieva, 2017, p. 1).

\section{The EU engagement in post Soviet Central Asia}

With the dissolution of the USSR social scientists raised questions such as "What should be the form of government for the newly born countries, and what were the appropriate institutional mechanisms for making and implementing policies while also ensuring regime survival?" (Menon, 2007, p. 3). On the first hand, the fall of communism opened promising challenges for the development of democratic and liberal political systems in Central and Eastern Europe, as well as in post-Soviet territory. However, when one compares Eastern European countries with Central Asia, as Gregory Gleason argues "all Central Asian countries did not fight for their independence" (Gleason, 1997, p. 32) and in 1990s they all inherited with the Soviet political culture, whereas the NGO sector played a key role for regime changes movements in Central and Eastern Europe.

When western countries launched their democracy promotion and development projects in the region, it was expected that former soviet states might be able to make reforms in their economic and political system and transform into European-style market economies. Scholars also argued that successful democratic reforms of Eastern Europe could prove a model for Central Asia. However, after 25 years of independence, Central Asian countries are still headed by former communist leaders and there is no political space for opposition. 
What is characteristic to the post soviet Central Asia is that local regimes managed to retain their suppressive policies. Since the 1990s the number of political parties and factions increased in the region but it did not bring democratic elections. Opposition parties and factions exist symbolically and opposition leaders and human rights activists who are against the regime are in political asylum. Within this regards, one would ask what went wrong with the western launched projects in the EU neighborhood Central Asia? By some scholars view, before September 11 the EU and USA were not proactive enough in promoting either political or economic reform in the region. Martha Brill Olcott emphasized "supporting reform in Central Asia was neither a priority of the U.S. nor of Europe, and in most ways policy in this region became a hand-maiden of the policy toward Russia" (Olott, 2007, p. 1).

Mehrad Haghayeghi pointed out that "although in some republics independence brought about major structural changes that aimed at altering the institutional frameworks of politics, with the exception of Kyrgyzstan, power remained in the hands of the former communist leaders who so far have hindered the process of post-communist democratization" (Haghayeghi, 1996, p. 121). It can be explained with the fact that new independent Central Asian states inherited communist parties and communist leaders, whereby political transformation appeared unsuccessful.

With the dissolution of the USSR, former Soviet leaders from the Central Committee took presidential offices in young countries and reshaped their political ideology. For example, Turkmenistan and Uzbekistan aimed at preserving Soviet-era institutions such as kolkhoz, sovkhoz and the one-party system, while Tajikistan, Kyrgyzstan and Kazakhstan still see democracy as a threat to their existence. Thus, it would be interesting to analyze, what is the role of the EU engagement in democracy promotion in the region with the increased geopolitical interest of Russia and China in post Soviet Central Asia.

\section{The case of Kyrgyzstan}

In their analysis Nicklass Norling and Svante Kornel highlighted "Kyrgyzstan is the most democratic of the Central Asian countries and is often classified as a hybrid regime, combining democratic and authoritarian elements" (Norling, Kornel, 2016, p. 4). Among Central Asian countries, Kyrgyzstan differs with its active civil society. As local and international experts highlight Kyrgyzstan is the first Central Asian country, which have been experiencing civil society revival through mass movements and massive protests. For last two and half decade, Kyrgyz society already experienced two revolutions, which resulted withdrawal of authoritarian leaders.

From the early 1990s, the first president of the Kyrgyz Republic Askar Akaev had a different approach than other Central Asian presidents. His main slogan 'Kyrgyzstan is our common home' pursued the prevention of conflict in multiethnic Kyrgyz society and the same time this slogan had democratic meaning for diverse society. Askar Akaev's democratic and liberal view in early 1990s drove Kyrgyzstan for active involvement in international society through membership in international organizations. 
According to the assessment of 'International Crisis Group', ${ }^{4}$ in the first decade after independence, Kyrgyzstan was described as an island of democracy and stability in Central Asia. The Crisis Group highlighted that "in comparison with other countries in the region, it has indeed carried out deeper economic reforms and allowed more room for civil society and opposition political activity" (ICG report, 2001, p. 1). In contrast to other Central Asian countries, Kyrgyz society could preserve the active political participation of ordinary citizens. In contrast to other Central Asian countries, numbers of NGOs in Kyrgyzstan have been constantly increasing and Kyrgyzstan became the first Central Asian country which has experienced the revival of the civil society sector through the involvement of the NGO sector. Therefore, when one compares democratic reforms in Central Asian countries, Kyrgyzstan has been described as the island of democracy due to an active civil society.

However, the model which was promoted by Askar Akaev failed to work due to economic fragility and heavy corruption in Kyrgyzstan. In addition, like in other Central Asian countries, family centered regime in Kyrgyzstan was one of the main root causes of protests. The president's family involvement in corruption and monopolization of the political and economic sector brought the failure of democracy promotion in Kyrgyzstan.

As most scholars argue Kyrgyzstan's 2005 "Tulip" revolution brought some hope for political system change. However, due to the strengthening of family centered regime by Bakiev, Kyrgyzstan witnessed the second revolution that took place in April 2010 and resulted death of 87 people and injured over 1500 people, civil society is still struggling with freedom of speech and democracy promotion. Regarding the post April 2010, Kathleen Collins suggested to "Kyrgyzstani and international proponents of democracy direct their focus beyond elections to seriously addressing the potentially devastating challenges of corruption and governance, ethno-nationalism and ethnic instability, and the need for a citizenry committed to the new democracy" (Collins, 2012 , p. 1). The case of two revolutions in Kyrgyzstan that has removed two authoritarian presidents demonstrates people attempt to change political system corrupted by family and clan politics.

In general context, comparing to other Central Asian states till last year Kyrgyzstan was identified as the quasi-democratic and with some elements of authoritarianism. However, already in February 2017 Freedom house and Human Rights Watch listed Kyrgyzstan together with all Central Asian countries as consolidated authoritarian regime. If several years back Kyrgyzstan was identified as an island of democracy in Central Asia with relatively active civil society in the region, for last few years the Kyrgyz government is also becoming intolerant to criticism and suppressive towards political opponents and human rights activists. Besides, journalists and human rights activists who reflected independent view and criticized presidents suppressive policy towards opposition are intimidated my presidents lawsuits. For instance, from March to April 2017 "the prosecutor general has

${ }^{4}$ Crisis Group is an International NGO which was founded in 1995 on the initiative of well-known transatlantic figures who dispared at the international community's failure to anticipate and respond effectively to the tragedies in the early 1990s in Balkans and Africa, information about the vision and mission statement of the organization is retrieved from NGO website: http://www.crisisgroup.org/en/ about.aspx. 
demanded 20 million soms (285.000 US dollars) from Taalaigul Toktakunova, a lawyer for the opposition Ata Meken party and Radio Azattyk, and three million soms (43,000 dollars) from other defendants including the Zanoza.kg, and 24.kg websites" (IWPR Central Asia, 2017, p. 1). Intimidation of Kyrgyz media by president's lawsuits and the recent arrest of Parliamentarian and opposition leader Omurbek Tekebaev on February 26, 2017, and accusations towards his follow party members and members of Jogorju Kengesh/Kyrgyz Parliament Almambet Shykmamatov and Aida Salyanova indicates political motivation of charges and revival of authoritarianism in Kyrgyzstan.

\section{The EU strategy for Kyrgyzstan}

The EU strategy to Kyrgyzstan, like to other Central Asian countries, have been in constant evolution since 1990s. If Partnership and Cooperation Agreement (PCA) since 1999 provided the legal framework for EU - Kyrgyz Republic cooperation that focused on political dialogue, economic relations and other sectors, including science, technology and culture, in 2007 the EU developed New Partnership with Kyrgyzstan which further pursued strengthening bilateral partnership.

While analyzing the EU partnership and strategy to Kyrgyzstan, it is important to mention about Multi-Annual Indicative Programme (MIP5) for Kyrgyz Republic 20142020 that pursues to consolidating the values of democracy, application of rule of law, good governance, and respect for human rights and fundamental freedoms, which have direct implication to sustainable and prosperous development of Kyrgyzstan. Therefore, in the analysis of MIP for Kyrgyz Republic it is clear that the focal sectors of support within the MIP 2014-2020 are the Rule of Law, Education and Integrated Rural Development. The EU strategy which focuses on neo-liberal approach that aim at strengthening democracy, human rights issues and application of rule of law in Kyrgyzstan, have been directly financed through the EU technical assistance program in the frame of PCA and current Multi-annual indicative program. As analysis show comparing to China and Russia, the EU focuses on democracy assistance in Kyrgyzstan.

There are scholars who raise questions such as, why democracy progress and human rights issue in Kyrgyzstan, which is geographically and geopolitically far from Brussels, matters the EU? and why the EU should care about democracy promotion in Central Asian when the region is already under heavy influence of Russia and China? The first answer is that European common values such as respect for human rights, freedom (including freedom of speech and assembly) the rule of law, justice, solidarity, gender equality and other fundamental principles of human rights founded the EU. Democratic principles of the EU are seen as centerpiece of engagement not only in its neighborhood policy but also in global context.

It is argued that Central Asian regimes see democracy as a threat to their existence and are more comfortable with Russian and Chinese support through regional integration, focusing on political, economic and security context. The lack of interest or passive cooperation of Central Asian countries with the EU, by some scholars view derives from

${ }^{5}$ The MIP 2014-2020 allocates $€ 184$ million to the Kyrgyz Republic for the period 2014-2020. In comparison with the allocation for 2007-2013 the amount increased by $74 \%$. 
the Central Asian leaders ambition to preserve their family centered regimes and with Moscow's attempt to derail the EU initiatives in the post-Soviet region. The current civil society and media crackdown in Kyrgyzstan is also connected not only with president Atambaev's ambition to establish authoritarian regime, but also with the external support from Russia and China, which do not accommodate open civil society. Both Russia and China led regional institutions Shanghais Cooperation organization and Collective Security Treaty organization does not give any space for civil society sector. Both of these institutions are focused on Security challenges and politico-military cooperation, whereas human rights issues, free media and civil society topic is beyond the agenda.

The criticism towards Shanghai cooperation organizations derives from the initial goal of China led institution, which aimed at developing good neighborhood policy with Central Asia and the same time to control over ethnic minorities Xinjiang Uyghur Autonomous Region (XUAR). When Central Asian states are involved in joint approaches of SCO in fighting against terrorism, separatism and extremism, human rights issues connected with minorities rights is in threat. It appears as an instrument to control over minorities and vulnerable groups.

\section{Conclusion}

The EU engagement in Central Asia is only hope for democratic change. Today, when Central Asian states are involved in tight cooperation with Russia and China, when both historical overlords of the region extended their geopolitical interest, a certain number of scholars argue that Central Asian states should further strengthen their relations with both powerful players in the region, due to Chinese economic growth which already is ranked in the first place and due to Russia's proximity that has returned its status of security guarantor with Russia's active engagement in Syria. Indisputably, regional challenges including security and economic issues can not be solved without participation of Russia and China. However, it would be wrong to exclude the role of the EU and western countries in Central Asia for stability. Stability and development in Central Asia will take place only when illness of economy such as corruption and family regimes will be eradicated. Regional cooperation of Central Asian countries with China and Russia do not consider addressing fights against corruption or democratic governance. Therefore, the role of the EU funded projects is crucial to civil society development and democracy promotion for Kyrgyzstan as well as to other Central Asian countries.

\section{Bibliography}

Boonstra J. (2015), Reviewing the EU's approach to Central Asia, Open Society Foundation, EUCAM \#34, February.

Collins K. (2012), After the Kyrgyz Spring: Challenges to Democratic Deepening, "The Brown Journal of World Affairs," vol. 19, no. 1.

Demes P. (2010), Twenty Years of Western Democracy Assistance in Central and Eastern Europe, International IDEA, Stockholm. 
Gleason G. (1997), Central Asian States: Discovering Independence, West view Press.

Haghayeghi M. (1996), Islam and Politics in Central Asia, Macmillan, Palgrave.

Institute for Wars and Peace Reporting (2017), President's Lawsuits Intimidate Kyrgyz Media, March 24, Kyrgyzstan, https://iwpr.net/global-voices/presidents-lawsuits-intimidate-kyrgyz-media

International Crisi Group, information about the vision and missionstatement of the NGO, http://www. crisisgroup.org.

International Crisis Group (2001), Kyrgyzstan at Ten: Trouble in the "Island of Democracy", Report 22/Europe \& Central Asia, 28 August.

International Media Support (2008), The examples of Kazakhstan and Kyrgyzstan: Political extremism, terrorism, and media in Central Asia, Copenhagen.

Kelly-Clark V. (2016), Why is Central Asia dumping Russia for China?, Global Risk Insights, May 23.

Khokhlova E., Freedom House classifies Kyrgyzstan as country with authoritarian regime, http://24. kg/english/48854_Freedom_House_classifies_Kyrgyzstan_as_country_with_authoritarian_regime/.

Manon R. (2007), Central Asia: Views from Washington, Moscow and Beijing, Published by M.E. Sharpe.

Marantidou V., Ralph A. C. (2014), China and Russia's Great Game in Central Asia, "Magazine The National Interest," https://nationalinterest.org/blog/the-buzz/china-russias-great-game-centralasia-11385.

Matveeva A. (2006), EU stakes in Central Asia, Institute for Security Studies, Paris.

Nicklass N., Svante K. (2016), The role of the European Union in democracy-building in Central Asia and the South Caucasus, International IDEA, Stockholm, Sweden.

Olcott M. B. (2007), Democracy Promotion in Central Asia: From High Expectations to Disillusionment, "Carnegie Endowment for International Peace," February 10.

Omelicheva M. Y. (2015), Democracy and Dictatorship in Central Asia, http://www.oxfordbibliographies.com/view/document/obo-9780199756223/obo-9780199756223-0060.xml.

Orozbekova C. (2016), Central Asia's Presidents-for-Life, http://thediplomat.com/2016/02/centralasias-presidents-for-life/.

Stratfor (2015), In Kazakhstan, Government Remains a Family Affair, October 21, https://worldview. stratfor.com/article/kazakhstan-government-remains-family-affair.

Tabaldieva D. (2017), Prospects for China - Kyrgyzstan Economic Relations in the Framework of the Silk Road Economic Belt Project, http://china-trade-research.hktdc.com/business-news/article/ The-Belt-and-Road-Initiative/Prospects-for-China-Kyrgyzstan-Economic-Relations-in-theFramework-of-the-Silk-Road-Economic-Belt-Project/obor/en/1/1X000000/1X0A9JIX.htm.

\section{Zaangażowanie Unii Europejskiej w promocję demokracji w postsowieckiej Azji Środkowej: przypadek Republiki Kirgizji - perspektywy i wyzwania}

\section{Streszczenie}

Po upadku Związku Radzieckiego zrodziły się różne hipotezy dotyczące reform demokratycznych i zmian w systemie politycznym w Kirgistanie. Uważano, że Kirgistan rozwinie niezależną politykę i demokratyczne rządy. Od początku lat 90. kraje europejskie - najpierw poprzez OBWE, a później przez UE - realizowały projekty rozwojowe, odgrywając centralną rolę w promowaniu demokracji i rozwoju społeczeństwa obywatelskiego w Azji Środkowej. Jednocześnie, jak pokazują analizy, sąsiadujące mocarstwa, takie jak Rosja i Chiny zintensyfikowały realizację swoich interesów geopolitycznych w regionie, co zaowocowało powstaniem regionalnych instytucji takich jak Szanghajska 
Organizacja Współpracy (SCO), Organizacja Bezpieczeństwa Zbiorowego (CSO), Euroazjatycka Unia Gospodarcza (EEU) i inicjatywa Nowego Jedwabnego Szlaku (SRBI). Będąc pełnoprawnym członkiem instytucji regionalnych, na czele których stoją Chiny i Rosja, Kirgistan znajduje się pod ich silnym wpływem politycznym i gospodarczym. Poza tym, sytuacja w zakresie praw człowieka w Kirgistanie, podobnie jak w innych krajach Azji Środkowej, pogarsza się w ostatnich latach.

Niniejszy artykuł koncentruje się na wzajemnych relacjach między Rosją i Chinami w zakresie dominacji geopolitycznej w regionie, $w$ tym na jej negatywnym wpływie przejawiającym się w niestabilności politycznej, tłumieniu społeczeństwa obywatelskiego i pogorszeniu się sytuacji w zakresie praw człowieka. $\mathrm{W}$ artykule analizuje się również zaangażowanie krajów europejskich w promowanie praw człowieka i demokracji w Kirgistanie. Za istotne uznano przeanalizowanie strategii UE w zakresie reform demokratycznych w Azji Środkowej i zbadanie, dlaczego mają one znaczenie dla UE.

Słowa kluczowe: Azja Środkowa, geopolityka, prawa człowieka, promocja demokracji 